\title{
CUSTOMER AWARENESS TOWARDS E BANKING SERVICES IN INDIA- A COMPARATIVE STUDY OF PUBLIC AND PRIVATE SECTOR BANKS
} \author{
SHILPA ARORA ${ }^{1}$ \& DR. PRIYANKA SINGH ${ }^{2}$ \\ ${ }^{I}$ Research Scholar, Faculty of Management Studies, Manav Rachna International Institute of Research \& Studies, Faridabad, \\ Haryana, India \\ ${ }^{2}$ Associate Professor, Faculty of Management Studies, Manav Rachna International Institute of Research and Studies,
} Faridabad, Haryana, India

\begin{abstract}
With the changing structure and development taken place after globalization and privatization and stringent policies of regulatory bodies and policy makers, concept of digital payments, payment banks and $E$ banking are occupying a great space in the dictionary of existing economy. These new technology based methods are posing pressure on the banks to move out of the cage of traditional structure and adopt new methods especially technology based methods to move step by step with the changing environment and for surviving in the highly competitive market. Changes in the banking industry are taking place rapidly and at a higher speed. Customers at present are no more left illiterate and unknown with new methods of banking. At this stage banks are required to adopt new methods for offering services to banks where customers are not only satisfied but retain in bank's database for a longer period of time. This paper will highlight on the customer awareness level about $E$ banking services offered by banks- public and private banks and will also compare two independent groups. The efforts have also been made to bring or list down few factors with the help of secondary literature responsible or can be related with the customer awareness level about $E$ banking services offered by banks.
\end{abstract}

KEYWORDS: Technology, Banking, Customer

Received: Jun 09, 2020; Accepted: Jun 29, 2020; Published: Aug 06, 2020; Paper Id.: IJMPERDJUN2020647

\section{INTRODUCTION}

Indian Banking system is currently under development and change. With the adoption of new technological tools and methods, Indian banking system has made a tremendous growth in its operations. Be it any sector, education, healthcare, manufacturing or banking all are somewhere or completely affected by the technology in one or the other aspect. With the advancement of methods technology has also brought challenges for the people working at operational level in different industry. For driving out the maximum benefits from the adoption of technology banks are putting a huge amount of money. Increase in number of ATMs, Tele banking facility, Mobile banking apps are some of the few examples of initiatives taken and investment made by the banks for their growth and increasing overall performance. Real time gross settlement etc proofs that RBI has also move step forward for the adoption of new technological tools and new payment methods on an ongoing basis. Based on the above factors one can easily conclude that Indian financial system has become more advanced and structured as compare to previous one.

No doubt, that arrival of economic reforms has put a drastic effect on the roof and walls of every industry. Nationalized entities were fully in their monopoly power till the time private entities were not allowed to enter into the markets. Before 1991, huge investment was made by government to uplift the public sector but no change took 
place neither in the growth pattern nor in performance index. After 1991, with the Liberalization, Privatization \& globalization, stringent policies were made relaxed and permission was given to private sector to shake hands with public sector to grow overall economy. These new reforms not only put challenges before economy but also shown the path of achievement of set goals in future with new structure and policies. New reforms have forced all sectors to grow by shaking hands with the new innovative and upcoming technological methods leaving behind old traditional structure. For a system to grow and in a healthy pattern, technology adoption is considered to be the best and effective way.

Adoption of new tools and introduction of new innovative methods and ways of offering services will not improve or change the picture of Indian banking till the time last pillar of supply chain ends on customer will not get satisfied. Positive response from the customers will only decide whether or not industry is able to perform or not.

With the intense and stiff competition in the markets among different players of same industry, it has become necessary for the banks to adopt customer centric approach rather than adopting product centric approach. Customers should be well aware about the product offered by banks and services provided by them in their benefit. This will result to increase customer base and retain existing customers in a healthy way. RBI has been actively taking steps time to time to introduce new ways and methods of providing services to customers at their door step and through mobile apps. Time to time improvement in the bank services and change in the work culture of banks are few examples of technology change in the sector. Core banking solution is one of the examples as contribution of technology in the banking sector which helps customer to access their accounts online irrespective of any branch.

Technology has put a huge list of tools and methods to make the work easier and make customers happy in one go but this can only be done if one is trained enough to put them in correct form and order to drive maximum benefits. Well said "Rome was not built in one day Like that positive impact of technology will not be seen in one day. It will surely give best results once adopted in right manner and with set objectives.

\section{LITERATURE REVIEW}

There have been interesting findings on the consumer behavior shown by users of mobile banking, the findings of Wadhe and Shamrao (2011) present particularly interesting inferences on this subject. After analyzing the different services on electronic modes of banking and perceptions regarding these services by the consumer they came to the conclusion that the customers aren't just aware of the plethora of services on offer but also possess knowledge about various transactions which can be done through online banking. Under the gambit of this study services like internet banking, tele-banking, ATM's and mobile banking were considered and the inferences churned out through rigor provided by subjecting the data through ANOVA tests for mean score analysis.

Furthermore, research work has been done by incorporating a myriad of parameters. One study done by Pipaliya (2012) has covered the concept exhaustively by analyzing the " 12 kinds of services which can serve some purpose to the consumer only with his/her awareness of them. The importance of these e-banking services is noticeable and the nuances of consumer behavior in this domain have been enhanced in authenticity by treating the data obtained through independent samples by t-test and f-test method. It also inferred that contrast in awareness levels about e-banking services amongst men and women as well as the older generation compared to the younger generation.

Satisfaction levels amongst the user of such services remain an important area of study; the results convey a more complete picture of the consumer perceptions. A study was conducted by Sumedha, Urvashi and Rajni (2012) on SBI 
customers had some peculiar findings. I $t$ concluded that passivity on behalf of the customer was resulting from inadequate legislations, security concerns and lack of knowledge about the e-banking field. It also suggested 'demos' included in the website for potential users can serve as an effective tool in improving awareness in the e-banking area and best practices for a trouble-free, secure experience.

The study by Elvarasi and Surulivel (2014) provides additional strength to the findings made by Pipaliya (2012). A study was conducted on SBI banks with 200 respondents to find out the preference patterns for using e-banking services. A stark contrast was evident in the higher preference level by the younger generation for e-banking compared to the older generation, a similar contrast can be observed amongst the sexes as women used e-banking services less frequently than Male respondents.

A sense of security associated with the use of a particular product 'service is an important predictor in the propensity of a consumer to avail that service/product. The study done by Iswarya (2015) in Tamil Nadu concluded that lack of acceptance towards modern banking methods stems from the lack of trustworthiness of the online medium for handling money, same pattern can be seen amongst the customers who do not use cards for shopping.

ATM'S have gained widespread acceptance in today's modern banking domain. ATM's are a critical pivot point for many contemporary banking services like 24 hour cash, net banking, mobile banking etc. Kumar and Vadivel (2016) observed that majority of the 300 respondents in Coimbatore city were happy with the performance of the ATM's of ICICI Bank whereas many of the respondents were not satisfied with the grievance settlement system of the banks.

Some differences in this area can be observed between the public, private and foreign banks. An exhaustive and comparative research was carried out by Tandon, Goel and Bishnoi (2016) by studying the responses of 450 consumers in the Delhi/NCR regions on a 5 point Likert Scale. It found that e-banking is the preferred choice of delivery channel in banks and that these modern methods of banking are gaining wide spread acceptance of the consumer. The data from the random samplings also showed the difference level amongst the awareness of a typical customer of a private bank vs. a public sector bank. The public sector banks have some work ahead to match the awareness created by their private sector/foreign counterparts in that respect.

Another one of the studies done by Shende and Khursange (2106) done one a sample size of 300 people found that $65 \%$ of the customers were aware of the e-banking services. It further proves that general awareness exists amongst majority of consumers, it also reinforced the earlier inferences made by previous studies that amongst the $35 \%$ of consumers who were not aware of e-banking, most respondents belonged to the over 40 years age group.

Research done by Paul, Mittal and Srivastava(2016) studied the impact of service quality and its impact on customer satisfaction. Factors like knowledge of product, ability to solve questions, fast service and response to need have a positive influence on satisfaction whereas factors like appearance and follow up have a negative impact on satisfaction in private sector banks.

The modern banking area with its latest offerings and services has transformed the way we bank. These transformational changes and seismic shifts in the banking domain present their own sets of challenges and opportunities. Agarwal S. and JainA.(2012) have explored this area with the view analyzing the effects of innovation in banking and its role in growth and development of the Indian Economy. The research based purely on secondary database suggested that the Indian Banking sector has experienced sizeable changes in the 2006 to 20115 year period like the landmark 
foreclosure law, fast spreading technological revolution and falling interest rates. The huge potential of the retail segment is good news indeed for Indian banks as long as macroeconomic environment prevails. It further concluded that the modern banking system emphasizes on creativity and innovation more than aggressively than in any point of time.

\section{RESEARCH METHODOLOGY}

\section{Objectives of the Research}

To study the awareness level of customers of both public and private banks towards the E-banking services offered by public and private sector banks in India

\section{Hypothesis}

- $\mathrm{H}_{0}=$ There is no significant difference between the awareness level of customers using $\mathrm{E}$ banking services at public and private sector banks.

- $\mathrm{H}_{1}=$ There is significant difference between the awareness level of customers using E banking services at public and private sector

\section{Data Collection Tools}

Considering all factors that can affect the awareness level of customers, questionnaire has been structured and circulated to the different categories of customers of both sets of banks-public and private banks. Questionnaire is divided into three sections- Part I was emphasizing on the questions related to general banking to know about the perception and knowledge of customers about the services offered by banks. Part II is divided into three sections in which first section contains questions related to awareness level of customers towards E banking services offered by banks. Customers of both groups (public and private banks) were targeted to fill the questionnaire. Questionnaire was circulated through online mode and few customers were targeted at bank branch only. They were requested to answer all questions on five point likert scale where numbers were reflecting responses as 1 - strongly agree, $2=$ agree, $3=$ neutral, $4=$ disagree and $5=$ Strongly disagree. Respondents were well informed about the objective of the research and given assurance that their responses were kept confidential and used totally for research purpose. For selecting the respondent's convenient sampling method has been used. Before approaching to large population, pilot study has been conducted with 77 respondents. The responses received from pilot study has also been recorded and added in final questionnaire data. large data base of customers were targeted but at last 207 questionnaires were found to be qualified as many of the customers were not ready to fill the questionnaire , few have filled incomplete and rest were biased in their answers. Finally, most of the questionnaires were dropped because of these reasons.

\section{Data Analysis}

Statistical tool were studied to find out the awareness level of customers of both sets of banks to get an outcome and accomplish set objective. $\mathrm{T}$ test for independent samples was found an appropriate tool to study awareness level of customers of both sets of banks. Statistical tool have been used by using SPSS (16 versions). 


\section{Reliability Analysis}

To ensure the reliability of data, Cronbach's Alpha value was collected for the respondents under pilot study and for the respondents of entire questionnaire also. The accepted value of Cronbach'sis 0.70 . For this study the value calculated and depicted below in the table:-

Table 1: Cronbach's Alpha Accepted Value for Observations used in the Questionnaire for Customers of both Sets of Banks (Public and Private Banks) using E Banking Services

\begin{tabular}{|c|c|c|c|}
\hline Variable & No. of Observations & \multicolumn{2}{|c|}{ Cronbach's Alpha Value } \\
\hline & & $\begin{array}{c}\text { Pilot Study } \\
(\mathrm{N}=77)\end{array}$ & $\begin{array}{c}\text { Completed Survey } \\
(\mathrm{N}=207)\end{array}$ \\
\hline Customer Awareness Level & 13 & 0.960 & 0.937 \\
\hline
\end{tabular}

T Test: This statistical tool basically studied to compare the two groups. For the given study T- Test has been used to compare the groups of customers of public and private sector banks to study the awareness level of customers towards E banking services offered by different sector banks. This test fulfills the above purpose in accomplishing the set objective. The analysis of the statistical tool used in the study has been discussed below:

Table 2

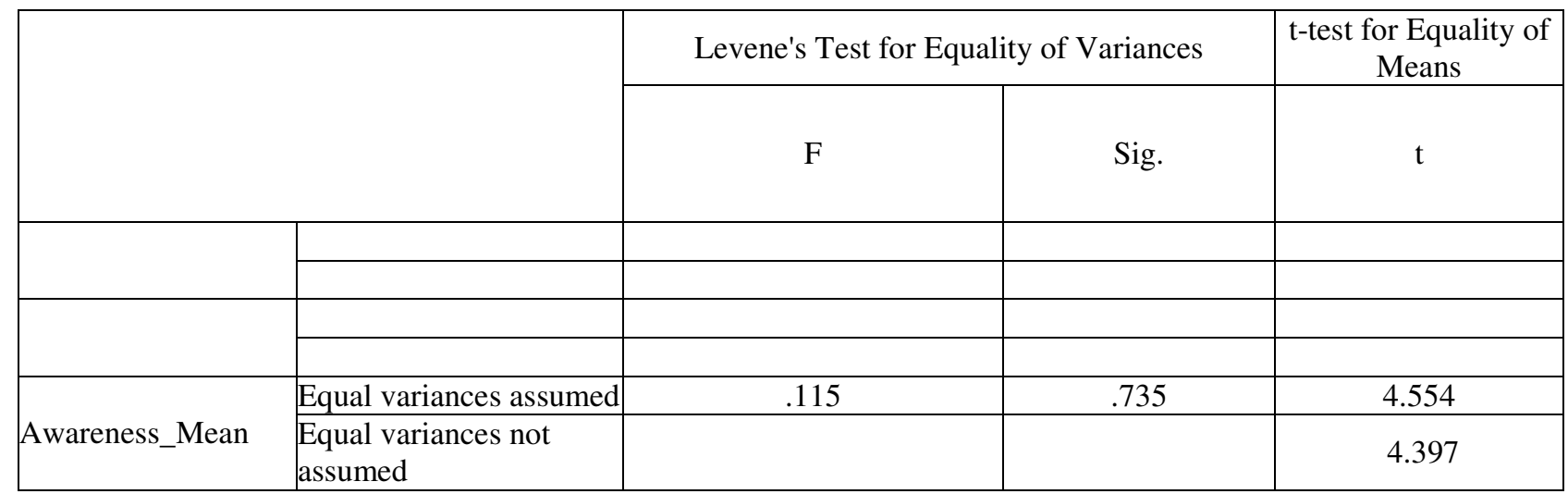

The above value in the table is above 1 which shows that there is significant difference in the awareness level of the customers of public sector and private sector towards the use of E banking services.

\section{CONCLUSIONS}

Banking sector has undergone number of developments related to technology in adopting new methods of offering services. This paper is an attempt to help the banks in knowing the stage of their customers related to perception towards the products offered by banks, their knowledge about the services and products offered by the banks and their problems if any related to the use of E banking services. In this study, it has been highlighted through primary and secondary literature that there is a difference in the awareness level of customers using E banking services offered by two different sets of banks. Also, through secondary literature few factors also come up which are responsible for the awareness level of customers like language problem, Employees insufficient knowledge about services, communication issue. Statistical analysis of data has proved that banks needs to adopt new methods and ways to make their customers aware about the services offered in their branches. It has been observed that public sector banks are little causal in their approach in telling their customers or giving them complete information about the services while on the other hand private sector banks are more proactive and adopt new ways to satisfy their customers in all ways. Their approach is customer centric rather than 
product centric, as their strategies revolve around their customers to find out the basic requirements of customers and their expectations from private entities.

\section{REFERENCES}

1. Yamunadevi, M. M., \&Selvan, M. C. Customers' Awareness on Various Services offered by Old and New Generation Private Sector Banks in Coimbatore District.

2. Surekha, M. E-Service Quality \& Customer Satisfaction A Comparative Study of Private \& Public Sector Banks.

3. Dhamija, Ankita, and DikshaSahni. "Green Banking: Perception and Willingness of Customers to Adapt Green Banking." International Journal of Financial Management 7.2 (2018): 1-8.

4. . Sumedha,K., Urvashi, K., \& Rajni, K.(2012). Analysis of SBI customer's attitude towards ebanking.International Journal of Science and Management, 4(1), 57-63 ...

5. Elavarasi, R., \&Surulivel, S. T. (2014).Customer awareness and preference towards e-banking services of banks (A study of SBI). International Research Journal of Business and Management, 4, 59-67.

6. Shah, Syed Nadeem Juman, Allah Rakhio Junejo, and Abdul Rehman Baloch. "E-Banking Issues Involves Through Service Oriented Architecture. "IASET: Journal of Applied and Natural Sciences (IASET: JANS) 2. 1, Jan - Apr 2016; 9-14

7. Iswarya, M. R. (2015). A Study on Consumer Awareness on Modern Banking Services in Theni (Dt). Int J Commer Bus Manag, 4, 823-31.

8. Tandon, A., Goel, M., \&Bishnoi, S. (2016). Consumer awareness towards internet banking: a comparative study of public, private and foreign banks. International Journal of Hybrid Inormation Technology, 9(6), 77-90.

9. Ajayi, Olusola Olajide, and Olufunke Esther Ajayi. "E-Learning: A Key to Actualizing Sustainable Educational Development in Africa. "International Journal of Computer Science and Engineering (IJCSE) 3.3, May 2014, 109-116

10. Shende, A., \&Khursange, S. (2014). The study of e-banking services, its awareness and uses among customers in India with special reference to Nagpur city. Apotheosis: Tirpude's National Journal of Business Research, 4(1), 156-167.

11. Paul, J., Mittal, A., \&Srivastav, G. (2016).Impact of service quality on customer satisfaction in private and public sector banks. International Journal of Bank Marketing.

12. Alsamydai, Mahmood Jasim, et al. "The factors influencing customer usage of mobile banking services in Jordan." International Journal of Business Management and Research 4.2 (2014): 63-78.

13. Agrawal, S., \& Jain, A. (2012).Technological advancement in Banking sector in India: Challenges ahead. 